\title{
MEANINGS OF EMERGING DISCOURSES FROM KENYAS’ AINSTREAM PRESS MEDIATIZATION OF SINO-KENYA RELATIONS
}

\author{
Josphat Ogweno Okech ${ }^{1 *}$ \\ *1Josphatogweno83@gmail.com, +2540729 554974 Rongo University Tutorial Fellow, Rongo University, Kenya
}

*Corresponding Author: -

Email: Josphatogweno83@gmail.com

\begin{abstract}
: -
Theoretically, the Kenyan press tends to be superficial in mediatizing Sino-Kenya relations. It is important therefore that the Kenyan mainstream press goes beyond the superficial mediatization of events on Sino-Kenya relations to play both a critical, inclusive, democratic and developmental role that suits the African continent. The tightening, multilevel and overarching social, political and economic relations are to a certain extent dependent on a critical analysis of the Kenyan mainstream press. The relation however is exhibited by the Kenyan mainstream press superficially and therefore the need to have a critical analysis of the selected newspapers. The study used the political economy and the mediatization theories to critically explore and get the discourses in the selected Kenyan Newspapers' mediatization of Sino-Kenya relations. This study therefore aimed at investigate the meanings of emerging discourses from Kenyas' mainstream press mediatization of Sino-Kenya relations. The study sought to answer the following question, what are the meanings of emerging discourses from Kenyas' mainstream press mediatization of Sino-Kenya relations? An explorative research design approach was adopted to address the question of meditization by the mainstream press on Sino-Kenya relations. Triangulation approach was used in the analysis. A two-step purposive sampling method was used in selecting first, the newspapers because they are market leaders and they are the newspapers that covered broadly the relations and then the period of study. The study evaluated three newspapers: The Daily Nation, The Standard and The Star. The study analysed articles in the newspapers between the year 2015 and 2019. Finally, relevant content was sampled that produce a sample size of 70 newspapers and 3 journalists and 3 Chief Editors who were purposefully sampled. Interviews were conducted with key informants and analyzed qualitatively while the coding sheet was used in collecting data then analysed quantitatively to record the frequency of occurrence of the identified nature of mediatization and qualitatively to study the meanings of emerging discourses, use of attributive words, pictures, and discussions and their inherent meanings from the discourses. The identified nature of mediatization were found to be fused with ideological undertones that served in mediatizing the Sino-Kenya relations. The results indicated that articles adopted neutral tone whose implication was a dual beneficial relation. The study suggested that the editorial policies of publishing houses should also be points of focus in future studies and should have a deeper discussion in its contents.
\end{abstract}

Keywords: - Mediatization, Media discourses, Meaning, Sino-Kenya, Press

\section{(우 (웅 (1)}




\section{INTRODUCTION}

\section{Background of the Study}

To date, western media globally have mostly narrated the story of China's engagement. Western media mostly look at China with suspicion on global level and it is regarded as an exploiting power on African continent Taylor, I. et al (2014). Often, it is framed in the context of land-grabbing, resource-snatching, neo-colonialism, and invasion.

Since the turn of the $21^{\text {st }}$ century, Western media have begun to focus on an emerging economic power the People's Republic of China. According to Le Pere, (2007), China has the potential to "grow into a power which is able to end the current unipolar system of U.S. dominance," as China is focused on increasing its economic, political, and military power. China's competition with the U.S. has been particularly evident in Africa in recent years. For decades, China's relations with Africa had focused on "checkbook diplomacy" providing aid in exchange for diplomatic recognition of Beijing instead of Taiwan (Bräutigam, 2011; Sun \& Olin-Ammentorp, 2014). However, China has now shifted its approach by increasing trade and investment, rather than focusing solely on aid to achieve its policy goals abroad. China's progressive push into Africa has drawn considerable scrutiny from Western leaders, which is further perpetuated by Western media who criticize China's environmental and labor standards, as well as China's no-strings attached policy, which advocates non-interference in the countries with which it partners Bräutigam, (2011). To counter such negative news reports, China has embarked upon public diplomacy initiatives designed to improve its image, including an influx of Chinese news bureaus in East Africa (Taylor, I. et al 2014)

China's engagement with Africa has been under scrutiny from African media over the past years. Stories reported by the African media about the Chinese involvement in African countries have created a mixture of positive and negative perceptions of China. Proponents view China's engagement with Africa as a "winwin" relationship, where China acquires natural resources for its growing economy and finds new markets for its manufactured goods, while African countries need China's assistance for their socio-economic development (Carmody, 2011; Fergus, 2013; Kofi, 2014). Other observers suggested that China offers an alternative to Western hegemony in Africa. Traditional Western power players are being challenged by China because most of the African governments found China's non-interference approach to be more appealing than Western countries" "good governance" agenda (Alden \& Davies, 2006).

China embraced the marginalized countries in Africa referring to them as the developing brothers (Rich \& Recker, 2013). In May 1996, China's president Jiang Zemin paid a state visit to six African countries; Kenya, Ethiopia, Egypt, Mali, Namibia and Zimbabwe (Zhang \& Matingwina, 2014). This marked the beginning of

China's renewed interest in Africa with the Chinese investment activity in Africa skyrocketing in the years that followed. China formalized its relations with Africa through the Forum on China-Africa Cooperation (FOCAC) in 2000 (Taylor, 2004). China is currently Africa's largest trading partner (Muekalia, 2014) than any other developed country. There were many goals behind improving the Sino-African relations. The first goal was securing African support in China's diplomatic battles with Taiwan Republic of China (Xiaoling, 2013).

The Changing Nature of Sino-African is understood in the analysis distinguishes between four different periods depicting the evolution of Sino-African relations since the creation of the People's Republic of China (PRC) in 1949. The chosen periods reflect both the political and economic perspectives of this relationship, particularly the major underlying forces that underpin this relationship. The periods also reflect how the political and economic dimensions of this relationship have changed over the past decades as China develops into the global power, and the second largest economy it is today. China's contemporary relations and engagement with the African continent are widely recognized (Large, 2008).

However, it is worth noting that the 'dragon' has not just arrived (Jiang, 2009). African countries have more than half a century of interactions with China (Achberger, 2010) that can be related to certain historical periods. Each period is characterized by political or economic factors that have helped shape the nature of this relationship over the past five decades as well as presently: the era of self-determination, the era of open door policies, the postTiananmen Square era and the period after the launch of the 'Go Global' policy. The final period may be described as the period of the formulation, and implementation of the 'Go Global' strategy from the year 2000 and onwards. The birth of this policy marked the rising strength of the Chinese economy and notably the birth of the CMNE - highly competitive, and prepared to engage in value-added activities in various locations of the world wherever the opportunities arise. Such an approach to FDI meant that African countries despite their highly risky environments for business became a popular destination for Chinese capital due to its wealth in energy, and natural resources Jiang, (2009). Thus, the beginning of the $21^{\text {st }}$ century witnessed a significant re-engagement with Africa both politically and economically on a scale never seen since the time of the Bandung conference of 1955. We elaborate on each of the above four periods of the Sino-African relations below showing how the relationship has evolved over the decades to China's current re-engagement with Africa. The recognition of the People's Republic of China in the United Nations had much to do with the votes of 26 African countries in the United Nations Wei, (1982), thus marking the event as perhaps the most significant in Sino-African relations.

However, the media in Africa have also often been accused of promoting various negative effects on their audiences, such as violence, discrimination and conflict (Kamau, 2007). These allegations are based on the assumption that media discourse is important in shaping the images and events as received by their audiences. Thus, how the media report about various social issues affects not only their audiences understanding of them but also what they perceive to be the right way to relate to these issues. This line of thinking is further enhanced by the growing realization that media is often not a mirror of reality, but rather a mediatization of the world, and that all these mediatization being selective make it impossible to have an absolute truth about media representations (Schudson, 2003). Therein then lays the need in continuous examination of the various mediatization mechanisms/nature employed by the media (Schudson, 2003). 
It is against this backdrop that the Kenyan press have actively mediatized on Sino-Kenya relations. However, questions bordering on the depth of their content have continued to be raised, based on how they have covered the China-Kenya relations (Tull, 2006). For example, a study conducted by (Neuendorf, 2002) on some of the mainstream media outlets discovered that the press, because of their need to fill the newspapers with content and working in an environment where they have to compete for the scope, have been in a hurry to report on the ChinaKenya relations with each development deemed newsworthy which in turn may have greatly impacted on the quality of information provided (Neuendorf, 2002). This then sets the stage for further analysis of the mainstream press content to decode the overarching mediatization of China-Kenya relations by the Kenyan press to establish the depth of the messages received by the Kenyan public regarding it.

Relations with Africa are still the most important and reliable part of China's foreign relations with developing countries (Zhang, 2014). If there was anxiety in Africa that the global financial crisis might reduce China's interest in the continent, Chinese President Hu Jintao provided some political reassurance during his visit in February 2009, as he committed to 'fully and punctually implement measures agreed at the Beijing Summit of the Forum on China Africa Cooperation, 'seek China-Africa pragmatic relations and promote the further development of our new strategic (Chui, 2007). At the November 2009 FOCAC meeting China reaffirmed its commitment to maintain the level of ODA and investment flows to Africa in the wake of the financial crisis, and pledged $\$ 10$ billion in concessional loans to Africa, as well as a loan of $\$ 1$ billion for small and medium-sized African businesses. As noted above, China also has providing substantial debt relief to 33 African countries (FOCAC, 2006). China's commitment to maintaining development assistance is particularly welcome, as there is a risk that ODA flows might be reduced by traditional development partners due to the deterioration of their national budgets. In addition, in what it called "a major step for Sino-African co-operation", the China-Africa Development Fund (CADFund) opened its first representative office in Africa on $16^{\text {th }}$.

The Sino-Kenya relation dates back to $14^{\text {th }}$ December 1963, when China opened her embassy in Nairobi (Kamau, 2007). According to Onjala (2008), the Chinese embassy in Kenya is arguably their largest embassy in Africa both in terms of size and employees. The early post-independence period saw fairly developed bilateral ties between the two countries. However, after 1965, this relation was lowered to the level of agency diplomacy when Kenya declared the Chinese charge' d' affaires persona non grata ordering him out of Kenya. In response China expelled the Kenya charge'd' affaires (East African Standard, Nairobi, 8 June 1967, p. 6). Nevertheless, towards the beginning of the 1970s, it gradually began to return to normal diplomatic relation as they restored the embassy relationship (Onjala, 2008).

According to Mingxun \& Robertson, (2013) China has enhanced its presence in Kenya in infrastructure such as the construction of the Nairobi-Thika superhighway. China also established Confucius institutes in local universities such as Kenyatta University and University of Nairobi to teach Mandarin. Other areas of aid provided by China to Kenya include renovation of the Moi International sports Centre Kasarani, methane generating pit and the expansion project of Moi Teaching and Referral Hospital in Eldoret. Kenya was also granted the preferred Tourist Destination in 2004, thus arrivals from China have doubled (Kaplinsky, 2007). In 2012, an estimated

41,000 Chinese visited Kenya for business and pleasure (Odhiambo, 2012). There have also been increased Foreign Direct Investment (FDI) in Kenya by the Chinese business community in the fields of infrastructure, education, agriculture and mining (Onjalla, 2008).

\section{Statement of the Problem}

Theoretically, the Kenyan press tends to be superficial in mediatizing Sino-Kenya relations. It is important therefore that the Kenyan mainstream press goes beyond the superficial mediatization of events on Sino-Kenya relations to play both a critical, inclusive, democratic and developmental role that suits the African continent. The tightening, multilevel and overarching social, political and economic relations are to a certain extent dependent on a critical analysis of the Kenyan mainstream press. The relation however is exhibited by the Kenyan mainstream press superficially and therefore the need to have a critical analysis of the newspapers. The media in Africa has often been accused of promoting various negative effects on their audiences, such as violence, discrimination and conflict (Kamau, 2007). These allegations are based on the assumption that media discourse is important in shaping the images and events as received by their audiences. Thus, how the media report about various social issues affects not only their audiences understanding of them but also what they perceive to be the right way to relate to these issues. This line of thinking is further enhanced by the growing realization that media is often not a mirror of reality, but rather a mediatization of the world, and that all these mediatization being selective make it impossible to have an absolute truth about media representations (Schudson, 2003) therein then lays the need in continuous examination of the various mediatization mechanisms/nature employed by the media (Schudson, 2003; Lynch \& McGoldrick, 2005).

It is against this backdrop that the Kenyan press have actively mediatized on Sino-Kenya relations. However, questions bordering on the depth of their content have continued to be raised, based on how they have covered the China-Kenya relations (Tull, 2006). For example, a study conducted by (Neuendorf, 2002) on some of the mainstream media outlets discovered that the press, because of their need to fill the newspapers with content and working in an environment where they have to compete for the scoop, have been in a hurry to report on the ChinaKenya relations with each development deemed newsworthy which in turn may have greatly impacted on the quality of information provided (Neuendorf, 2002). This then sets the stage for further analysis of the mainstream press content to decode the overarching mediatization of China-Kenya relations by the Kenyan press to establish the depth of the messages received by the Kenyan public regarding it. 


\section{The Meanings of Discourse of the mediatization}

Orgad, (2012) argues that the meaning decoded from a text is not necessarily the meaning, which the creator selfconsciously encoded. The meanings that readers find in newspaper comic strips used to mediatize Sino-Kenya relations, for example, are seldom consciously placed there by their creators. These cartoon codes are open texts or schematized structures whose content the reader fills in. Such blank outlines permit a great deal of semiotic movement on the part of the readers in making sense of them. The analogies, for example, relate China to a state that advocates for win-win relations it is important to note that when the selected newspapers referred to the negative events in Sino-Kenya relations they used intertexts and analogies that drew negative indexical attention to the objects they inferred to the interpretant. In this case, it drew attention to the negative events that took place between China and Kenya. These kinds of mediatization reinforce the discourse of mutuality in the relationship and the idea that it has to be advocated by internal and external actors. The concept of mediatization is based on the idea that connections between signs and symbols form particular meanings and reflect some aspect of reality (Newbold et al., 2002). Laughey, (2009) emphasizes the view that mediatization involves the use of symbols and images to create meaning in a discourse. Laughey, (2009) explains that if mediatization can be considered as a method of identifying real things, then the media are very important suppliers and sources of meaning. It is crucial to understand that mediatization does not occur solely in order to describe real things; it also forms part of our construction and understanding of reality. This means that mediatization shares the real meaning of the object in question. However, understanding meaning in mediatization is not an accurate means of understanding real meaning because a reflection cannot fully represent reality, even though it attests to what that reality means (Laughey, 2009). According to Laughey, (2009), mediatization is controlled by ideology, which may be defined as the process of mobilizing meaning to maintain a dominant relation (Orgad, 2012).

Thus, the press is useful as a supplier of information, as a means of structuring meaning, but it cannot inform to the same degree as real-life experiences (Laughey, 2009). Not everyone sees reality or the mediatization of that reality in the same way and people do not have complete freedom in their interpretation of reality. This is because the way people view a mediatized issue has to be within a structure of meaning (Laughey, 2009), or what is commonly referred to as a frame.

\section{Methodology \\ Philosophical paradigm}

This study investigates how China-Kenya relations is mediatized in The Daily Nation and The Standard newspapers, using the philosophy of interpretivism that explores the rationale in issues raised about Sino-Kenya relations. In contrast, the philosophy of positivism is used to provide the study with the required information, such as reflections or intuitions of issues of Sino-Kenya relations. However, the cornerstone of this research is the interpretation of frames/themes in order to explain the motives and purposes behind decisions of newspaper mediatization. This can best be done by means of text analysis, which will help the researcher to understand situations or positions that dictate the relevance of news creation in the newspapers, which is the main subject of the study.

\section{Research Design}

An exploratory design was adopted in this study. Creswell, (2008) described as a collection of Sequential procedures, in which the researcher seeks to elaborate on, or expand, the findings of one method with another method. The design is appropriate for this thesis because it helped do an in-depth analysis of the way the meanings of the emerging discourse in the selected newspapers mediatizes Sino- Kenya relations. This method is ideal because my study is based on a critical discourse evaluation of contents in the study. This involved beginning with a qualitative method for exploratory purposes and following up with a quantitative method with a large sample so that the researcher can generalize results to a population. Alternatively, the study begun with a quantitative method in which theories or concepts were tested, and was followed by a qualitative method involving detailed exploration with a few cases or individuals.

The rationale for using this approach was that the quantitative data and their subsequent analysis gave a general conception of the research problem in the current study, which explored on the issues that Sino-Kenya relations face and how they were mediatized by the selected Kenyan newspapers. The qualitative data collection and analysis elucidated on these statistical findings by exploring the meaning of the data in more depth, Creswell, (2003). Many researchers explore the merits and demerits of the mixed methods research approach (Creswell, 2003; Moghaddam et al., 2003). The merits of this method include straight forwardness and increased opportunities for the discovery of the quantitative findings in a specific way. However, the limitations of this design include the length of time taken and the feasibility of resources needed to collect and analyse both types of data, (Ivankova, 2015).

This study used the approach in three phases, which provided the structure to measure news stories. The first step was to rely on the information obtained from the quantitative data, which analysed the stories in order to understand the issues of Sino-Kenya relations which the newspapers focused on. Whilst the results of quantitative analysis provided a useful method for gathering information from a large number of stories, this method, for the purposes of this study was not enough to draw conclusions about the stories related to the area of study as it was not in-depth enough and required a qualitative assessment to be done. To explore the implications of mediatization of Sino-Kenya relations in more depth, the qualitative content analysis was used.

Further, it enabled the researcher to incorporate human experience. The researcher was able to overcome the weaknesses of intrinsic biases and the problems that come from single research method. However, qualitative content analysis was predominantly used because the research in mediatization of reality by the media is usually qualitative by nature. Quantitative content analysis method was used to count the frequency of occurrence of three major units of analysis 
namely; political, economic and cultural units. These units were identified as textual dimensions wherein they would help to inform qualitative analysis. Qualitative method involved the use of themes that included the use of tone and attributive words.

\section{Study Area}

The study area was the Kenyan mainstream press, where The Standard, The Daily Nation and The Star newspapers. Print media was selected because there is significant evidence showing that newspapers in particular, regularly serve to shape popular attitudes and beliefs, as they act as agents of public education (Baillie, 1996).

Within the newspapers, the study focused on whole article. These articles consisted of hard news, reports written by reporters or journalists, with the aim of providing neutral and objective accounts of a particular issue. Hard news is fast paced news that is heavily promoted by newspapers and usually appears on the front pages of newspapers (Schudson, 2003).

\section{Target Population}

In research, the term 'population' does not necessarily mean people; it can be texts, institutions, or anything else under investigation. A population of interest is dependent on what the researcher is investigating (Deacon et al., 2007). Generally, qualitative research design does not generate data that can be generalized to a greater population. Therefore, the selected sample of analysis is from a population deemed to be suitable to address my research objectives. In my study, the population of interest is the articles and news about Sino-Kenya relations that made headlines in three selected newspapers; The Daily Nation, The Standard Newspaper and The Star published between 2014 and ending 2019 covering a period of five years. It is from these targeted newspaper copies that the researcher relied on as an accurate and representative population for study. For the interview segment, the target population was 808 accredited journalists; 390 from The Standard Media and 378 from Nation Media and 40 from the Star newspapers respectively (Media Council of Kenya, 2020).

\section{Sample size}

Previous studies on getting a sample size for newspaper analysis, beginning with Stempel's in 1952, have shown that the cyclic nature of media content can render simple random sampling inefficient (i.e., more editions must be sampled), compared to other types of sampling. For example, daily papers vary from day to day during a week because of the advertising cycle, and simple random sampling can over-sample large-news whole Wednesday and Sunday editions and under-sample scanty Saturday editions.

One solution to the problem of systematic content variation in daily newspapers is stratified sampling that yields constructed weeks. Constructed week samples involve identifying all Mondays, and randomly selecting one Monday, then identifying all Tuesdays, and randomly selecting one Tuesday, etc., to construct a week that ensures that each source of cyclic variation - each day of the week - is represented equally. This stratified sampling presumably controls for sources of "systematic variation."

Lacy, Riffe, Stoddard, Martin, and Chang (2001) outline the procedures for constructing a week sample: identify each day of the week for the time period that you wish to research, then randomly select one day that represents each day of the week. Lacy et al. (2001) further concluded that nine constructed weeks during a five-year period were as representative as two constructed weeks from each year, if the variables being analyzed did not show great variance.

This study used purposive sampling because, according to Krippendorff, (2003), newspaper units are counted purposively and content analysts can use sample letters, terms or issues of a newspaper to answer research questions by enumerating sentences or interpreting details. The Researcher searched for Keywords used in this data to come up with a sample size: "Sino-Kenya! Or China-Kenya relations or Sino-Kenya relations!" Only articles that directly related to China's engagement in Kenya were included in the analysis. The results of the search were screened in order to eliminate duplicate and irrelevant results. The initial keyword search of articles found 50 articles of the Daily Nation and 70 news articles of The Standard and 30 for The Star. After removing

80 duplicated and not relevant articles, 70 articles were identified and focused on the topic of China's - Kenya relations. Among them, 20 articles were published by the Daily Nation and 40 articles appeared in The Standard and 10 The Star. The specific data analytic steps employed conducted the thematic analysis are as follows: first, retrieved the most relevant news articles used the combination of search words mentioned above. Then, each news article was read carefully to underline aspects of the texts that were relevant to China's current engagement in Kenya. Next, a second immersive reading was conducted to take notes of recurrent themes of China's presence in Kenya that were selected and narrated by the newspapers. Finally, a repeated reading of each text was done where themes were clarified, and important meanings were distinguished. News texts from both newspapers were constantly compared to distinguish the similarities and differences between their coverage.

Researcher read each article and the 70 that met any of the following exclusion criteria: article is from daily edition; article is from the news articles, sports, opinion pages, commentaries; article should have a word count of 50-3,000 words. The exclusion criteria were chosen to ensure that the sample contained only news articles relevant to the issue of Sino-Kenya relations. Following the application of the exclusion criteria therefore 70 articles remained. The majority of the sampled articles were collected from an online resource. Articles on the two newspapers were collected from the on-line archive and newspaper websites and some from hard copies. The basic unit of analysis was whole news story. The coding instrument consisted of the name of the newspaper, year of publication, themes of news stories, major issues closely related to Sino-Kenya relations and three news frames in the study. 
The sample size for the newspapers was obtained using the researcher's own formula given as:

Daily Nation newspaper before screening (n 1$)=20$

The Standard newspaper before screening (n 2) $=40$

The Star newspaper before screening (n 3) $=10$

Daily Nation newspaper before screening (n 1$)=20$

The Standard newspaper before screening (n 2) $=40$

The Star newspaper before screening (n 3 ) $=10$

$\mathrm{N}_{1}=1823$ (Nation)

$\mathrm{N}_{2}=1823$ (Standard)

$\mathrm{N}_{3}=1823$ (Star)

$\frac{\mathrm{N} 1}{S_{K^{1}}}=20, \frac{\mathrm{N} 2}{S_{K^{2}}}=40$ and $\frac{\mathrm{N} 3}{S_{K^{3}}}=10$

Where $S_{K} 1=$ Screened stories on Sino-Kenya relations in the Daily Nation

$S_{K} 2=$ Screened stories on Sino-Kenya relations in the Standard newspaper

$S_{K} 3=$ Screened stories on Sino-Kenya relations in The Star

$\mathrm{n}_{1}=S^{N} K 1$ (Nation) and $\mathrm{n}_{2}={ }^{S} \_{ }^{N} K 2$ (The Standard) and $\mathrm{n}_{3=}{ }^{S N} K 3 \quad S_{K} 1 \simeq 91$ and $S_{K} 2 \simeq 46$ and $S_{K} 3 \simeq 182 \mathrm{n}$

$=\mathrm{n} 1+\mathrm{n} 2+\mathrm{n} 3$

Therefore, the sample size is given as $n=\left\{\left(\frac{N}{S_{K^{1}}}\right)+\left(\frac{N}{S_{K^{2}}}\right)\right\}$

$\frac{1823}{91.15}+\frac{1823}{45.58}+\frac{1823}{182.3}=69.99$

$$
n \simeq 70
$$

Taking into consideration that an almost similar study on a Comparative Analysis of Chinese, Western and African Media Discourse in the Representation of China's Expansion of Economic Engagements in Africa by Wei, (2015) conducted 4 qualitative interviews, this study sought to balance between recommendations and practice and hence settled on 4 participants for the interview. And 3 Chief editors drawn from each of the newspapers in the study.

\section{Sampling Procedures}

Sampling was completed in two stages. First, the amount of published material relating to Sino-Kenya relations was narrowed down, and second, the content for analysis was selected from all the units in the sampling frame using a list of the frequency of common words to observe if they are related to the main issue of the news story. The material collected from the newspapers was divided into two steps. First, every news story about Sino-Kenya from 2015 to 2019 was collected from the two specified newspapers. This step helped to determine how many news stories were published, and what types of issues were addressed and how the newspaper deal with the information sources. Second, two of the most common issues were chosen for the study and visual and text analyses were carried out to discuss the type of predominant themes therefore a sample of 70 newspapers were considered

This sample period is considered appropriate for the present study because it covers a variety of media content that spans a wide area with sufficient content of China's engagement in Kenya. Editorials, news, and features articles will be the units of analysis because theme analysis favors whole articles as the main discourse unit (Umejei, 2013).

Testing sampling efficiency for inferring to a five-year population of newspaper editions required three steps: (1) calculating population parameters for the five-year population; (2) drawing random stratified samples in sets of 50 for various numbers of weeks and calculating how well they estimate the population parameters; and (3) determining which size (number of weeks) stratified samples were most effective.

Purposive sampling technique, was used which demanded that only two reporters/journalists be selected because they were the people of interest in the study by virtue of their position as key gatekeepers. The study was concerned with finding out the factors that influenced the selected newspapers mediatization of the Sino-Kenya relations from the producers or those who act as gatekeepers of such texts.

The sampling procedure entailed a three-step approach as proposed by Newbold et al., (2002), involving first the selection of media form and genre, then selecting the period that formed the parameters of the study and finally sampling relevant content from the selected newspaper copies. In this study, three newspapers were selected for analysis and the genre of the articles analysed were whole story articles.

This study follows Kaitlynn Mendes's logic in using newspapers for the data collection instead of any other medium such as Television or Radio. With regard to this preference Kaitlynn Mendes argued that she:

"... selected newspapers because their daily publication and wide circulation give them potential for quickly disseminating timely information about the women's movement to millions each day. Newspapers also present a forum for many types of styles - news, features, editorials, comment, letters to the editor comment, advertisements and cartoons - all in the same publication" (2011)

\section{Data Collection Instruments}

Both primary and secondary data were used in the study. Primary data was obtained by reading through the sampled news articles in order to identify the information needed in the study that eventually provided the data that was analysed. The unit of analysis was an entire news article including any photograph in it. A coding sheet was used to identify page lead stories relevant to the research question and research objectives. The coding sheet was employed to reduce the newspaper content into categories that were consistent with the objectives of the research. The coding categories used in the study 
were determined by the tenets of the mediatization theory; tone, discussions, photographs and themes. The categories helped in identifying the various mediatization mechanisms used by the newspapers and to analyse how the mechanisms were used in the news stories. The sample was used for analysis to determine the objectives and derive findings in this research.

\section{Interview Schedules}

Interview schedules was used to allow changes in the questions, seek clarification from the respondents' (Reporters) and the editors and was more personal to allow respondents give their opinion on Sino-Kenya relations in determining their editorial policies in regards to publishing articles that relate to Sino-Kenya relations

\section{Content Analysis}

Content analysis assesses forms of human communication, including books, newspapers and films, to identify patterns, themes or bias (Leedy \& Ormrod, 2010). Content analysis identifies specific characteristics from the content by verbal, visual and behavioural pattern analysis (Williams, 2007).

Content analysis is a research method, which offers researchers an effective way to investigate media content, (Cooley, 2011). Hansen et al described content analysis as, "a research technique for the objective, systematic and quantitative description of the manifest content of communication." This analysis identifies and counts the amount of specific characteristics of text in order to be able to say something about the messages, images, representations of such texts and their broader social significance (Hansen et al., 1998). In this study, content analysis helped the researcher to understand the content of the newspaper-specific coverage of the Sino-Kenya relations. The purpose of using content analysis in this study is to independently extract subject from the cultural products related to media production (Leavy, 2000).

The content analysis tool was used to identify articles in the news and opinion pages that tackled areas that represent Sino-Kenya relations. The presence of such articles and their quantification provides an understanding of how China engagement in Kenya articles were displayed and covered. The quantification was accomplished by counting the number of stories in each of the Sino-Kenya relations themes that appears in the press. Quantification of the articles was performed by counting the frequencies of appearance in the selected pages. As mentioned earlier, the newspapers could be mediatizing themes on Social, Political, and economic relations. The three thematic issues were scored a point each, based on their frequency of appearance on The Daily Nation and The Standard dailies edit levels of newspaper articles, giving a total of three thematic levels. In addition, content analysis was to determine the level of importance that was attached to specific themes in the Sino-Kenya relations by conducting an analysis of the positioning of the articles in the newspaper under study. Coding was concentrated on articles that dealt with the editorial, political leaders, and citizens' utterances.

\section{Data Analysis, Presentation and Interpretation The meanings on the emerging Discourses of Sino-Kenya relations in the selected Newspapers}

In the analysis of meanings in the newspapers articles, the researcher looked at the frequency of use of words related to negative, positive and neutral relations connotations. This included the frequency of use of attributive words associated with one nation, as well as a critical analysis of phrases (analogies and intertexts) in the sentences and the use of photographs or cartoons. The number of times the words and phrases which connoted themes/discourses (social, political and economic) of relations were counted.

Focus were on the attributive words, phrases, and cartoons/captioned pictures and sentences related to Sino-Kenya relations. An attributive word is an adjective, or any other modifier, which precedes a word and it modifies it, and expresses an attribute. An example of an attributive word used in a phrase is, "China a threat to Kenya's economy". The word is attributive. If used as "is China a threat to Kenya's economy", then it is not attributive (Hildebrandt, 2004). The qualitative part of the analysis included interpretation of some of the interpretive sentences and phrases used in the newspapers to show the meanings there in.

\section{Attributive words}

According to the mediatization theory, the media when using the attributive words helps in mediatization of new phenomena in emotions that are easily understood by their audience Karlberg, (2005). This in turn makes it easier for the audience to make sense of the phenomenon by attaching emotions to the words they read. Conversely, in the current study and as shown in the phrases below from sampled extracts, it emerged in the study that attributive words were largely used to mediatize Sino-Kenya relations in the newspapers.

The Standard Tuesday, April 232019 "China a threat to Kenya's economy”. The word is attributive. Daily Nation Tuesday, September 2017 “Can China-Kenya cement the relationship” The Standard Monday, June 252019 "Letter from Africa: Kenya's love-hate relationship with Chinese traders"

The Standard Tuesday, July 102018 "Does China now own more than 70\% of Kenya's bilateral debt" The Standard Wednesday, January 072016 "Kenya getting raw deal from China, says new World Bank trade report” referring to Workers hired by China Civil Construction Company to construct the Dongo Kundu bypass road who were demonstrating demanding better pay, better working conditions and some days off. Daily Nation Monday, June 102018 "offloading of Chinese excess capacity in Africa, " this is Mr. Nantulya's assessment states on the level of Chinese excess export to Kenya 


\section{Photographs with captions/Cartoons}

The photographs with captions/cartoons used reinforced the subject of the story. Tomaselli (1996) argues that text should not be confused with a conventional mass of words linked to the page of a book, or images projected on a screen but rather the mental reconstruction of the idea, the thought, the associations, the image mentally generated by the act of reading, decoding or interpreting. Reading involves an active negotiation on the part of the interpreter and sometimes the meaning understood by the author of the photograph is not understood by the decoder (discrepant decoding). However, considering news writing as a conventional process, the photographs that were used to mediatize Sino-Kenya relations were characterized by eighther propaganda or good news logically. The conventional process used thus allowed for a significant fit between the semiotic instructions of how to read news as a genre and the general message usually inferred by viewers. Thus, the photographs about the Sino-Kenya relations were anchored to match the words in order to construct meaning. The meaning constructed was that which reinforced readers 'perceptions of the situation in the relation rather than challenging them.

There is a debate inside China on whether political interests or economic interests should represent China's top priority in its overall Kenyan strategy. In 2011, China's then-Premier Wen Jia- bao proudly stated that "China had selflessly assisted Africa when itself was the poorest. We did not exploit one single drop of oil or extract one single ton of minerals out of Kenya." Brautigam, (2009). This seems to suggest that Beijing views Kenya first and most keenly through the lens of political ties rather than economic benefits. Since China's political agenda has been a constant theme of Beijing's Africa strategy, Zhang, (2014) firmly argue that, with or without the economic benefits, Kenya's' invariably would have been important for China. However, the counterargument is that, despite Africa's political importance, China has elevated economic considerations to a much higher level in its domestic and foreign agenda (Wekesa, 2013).

In determining the discourses, the themes covered in the sample, table 4.11 shows the total number and the total percentage of the events covered in each category. It also shows the number of times each category occurred in each month of the sampled period. Identifying the discourse in a text involves looking for topics that repeatedly show up in the text. As discussed in the previous chapter, this was used to examine the ways in which the two newspapers mediatized Sino-Kenya relations. It was used to identify the key frames that dominated the mediatization of China's engagement in Kenya as presented. Discourse analysis involved examining keywords, sentences, catch-phrases, exemplars and depictions in headlines, leads, sources selection, quotes selection and concluding paragraphs in the text (De Vreese, 2005; Entman, 1993). This study employed quantitative discourse analysis because it was interested in how issues are mediatized in the newspaper in trying to investigate how The Daily Nation and The Standard Newspapers mediatize Sino-Kenya relations. A general analysis of the samples revealed three topics about Sino-Kenya relations as mediatized in The Daily Nation and The Standard Newspapers political ties, economic ties and cultural/social ties. With regard to what kind of frame the two newspapers use, the present analysis shows that the economic theme is dominant with $50 \%$ political theme with $18 \%$ and social theme with $8 \%$ respectively

\section{Figure 4.7. The Dominant Theme}

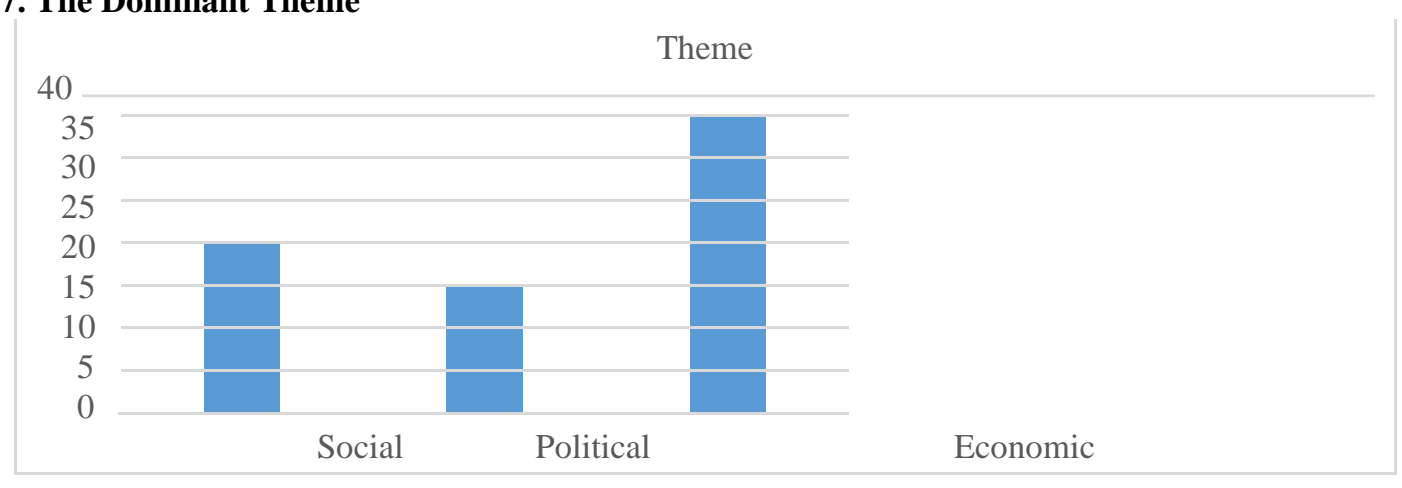

The analysis in this figure 4.7 has established that one dominant theme that represent Sino-Kenya relations was the economic frame.

\section{Mediatizing Economic discourse}

In order to stimulate Chinese investment in the tourism sector as well as resulting in direct flight connections between China and Kenya (and a number of African destinations), Kenya and other individual African countries have been granted "Approved Destination Status". Chinese tourism abroad is strongly regulated. The popular tourist destinations of Egypt and South Africa were the first countries to be granted such status. Following FOCAC's Addis Ababa Action Plan, China gave an additional eight countries (Ethiopia, Kenya, Tanzania, Zambia, Mauritius, Seychelles, Zimbabwe and Tunisia) such status. China and Kenya signed a memorandum for setting up the website "Kenya-China Economic and Trade Cooperation" in June 2006. The two sides agreed that China will import more coffee from Kenya and at the same time offered Kenya the most advanced coffee processing equipment. China's influence is not limited to raw materials. Kenyan universities are developing Chinese language programmes (University of Nairobi), Technical Scientific Cooperation (Egerton University), while Ministry of Information officials attend exchange schemes.

It is significant that these news stories emphasize the Chinese interest in Kenya in the context of describing their efforts to gain their place in world geopolitics by making inroads to Kenya economically. A large percentage of the news stories 
focused on the things that Chinese government could do to Kenya rather than making any that Kenya could do to China. The sentence "China and Kenya are working closely to see Kenya grow economically" is constantly repeated. This may be true, but the repetition of this sentence in the absence of other information about how Kenya is growing economically is likely to make readers feel that the story is one sided. In general, news stories in the two newspapers: The Daily Nation and The Standard, used the economic frame because they published many news stories which focused on the sad win-win narrative fronted by the Chinese.

These included for example "Based on the common aspiration of our two peoples, China-Kenya pragmatic cooperation has been flourishing. Infrastructural cooperation has covered various fields, including railways, roads, airports, ports, communication, housing, water supply and power" The Daily Nation Tuesday, April 232019

Another example was "This month, 55 outstanding Kenyan employees picked by Chinese enterprises are flying to China for a one-week visit. We believe they would enjoy hospitality of the Chinese people, witnessing China's development and achievements, and pushing forward more cooperation" The Daily Nation Tuesday, April 232019

The Standard Friday June 8 2018, also had a story that was economic "The first China International Import Expo will be held in Shanghai in November. It is a major policy initiative and commitment to the opening up of the Chinese market. Kenya, as a major exporting country in Africa, has been invited. In a few days, Mr. Wang Yang, member of the Standing Committee of the Political Bureau of the CPC Central Committee and chairman of the National Committee of the Chinese People and Political Consultative Conference (CPPCC), will visit Kenya at the invitation of National Assembly Speaker Justin Muturi. An ancient Chinese proverb says, "continuing success requires unremitting efforts". China-Kenya relations are at a new starting point with a brighter future"

The same Standard newspaper also had an economic frame story the same day in an editorial by Evis Ondieki "The very fact that the SGR story was included in a performance for the Chinese audience, he said, was proof of its importance to the Chinese officials. "We are happy to see that when Chinese people were celebrating the Spring Festival, a play about the SGR was staged on the Chinese New Year eve TV gala," said Mr. Gang."

\section{Extract 4}

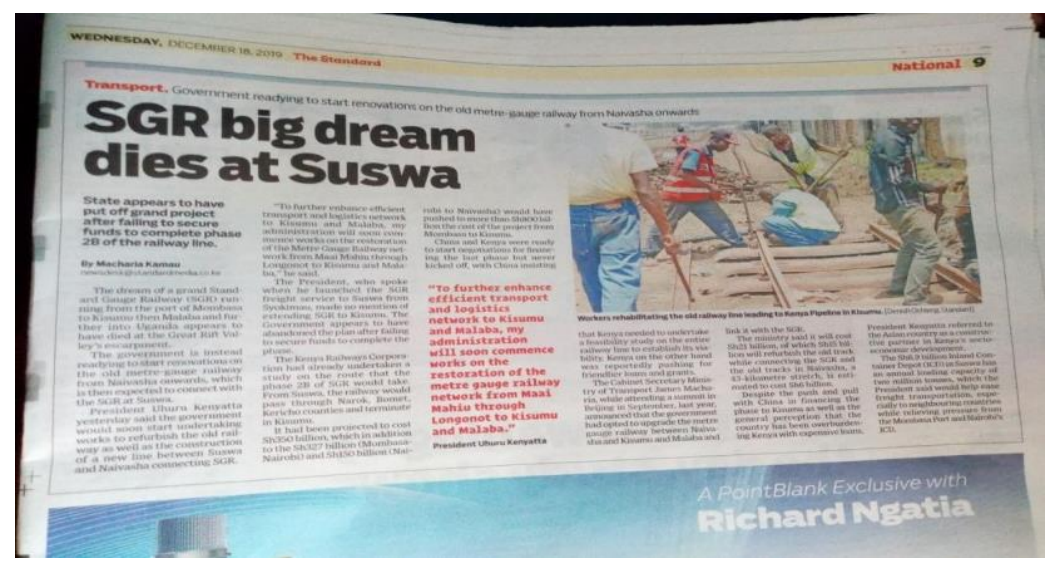

The Standard Friday June 82018 "Businesses cite biggest barriers in Africa” by Li Lianxing begins the first paragraph by saying "Chinese investors and potential investors have long regarded a good China-African relationship as a solid basis on which they can build success. But often when the uninitiated finally step onto the African soil they realize how simplistic the term "China-Africa relationship" really is. It goes on to report that "Fifty-three percent of the 75 Chinese companies sounded out in the survey said corruption is "a very significant obstacle" to doing business in Kenya, and 15 percent said it is "a significant obstacle". Sixty-three percent of respondents said crime, theft, disorder and personal safety were significant or very significant obstacles.

\section{Extract 5}

The Standard Tuesday May 132015 highlighted a story on tourism

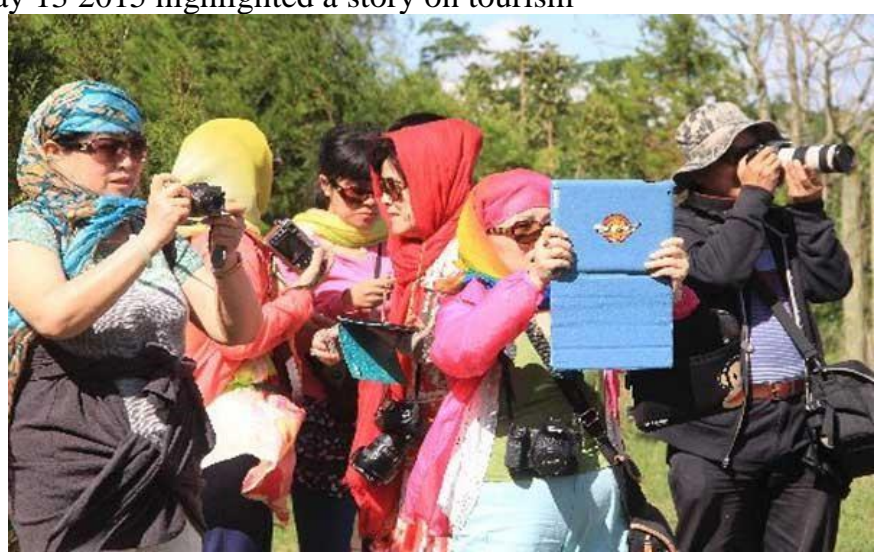


Figures show a decrease in the number of tourists from China as well as other source markets last year The China -Kenya relations were further boosted last year in November when the Kenya Airways launched the first ever direct flights from China to Kenya. The Kenya Tourism Board (KTB) has launched an aggressive marketing and awareness campaign to woo tourists from China following enhanced bilateral relations between the two countries, Managing Director Muriithi Ndegwa has said.

Mr. Ndegwa said they are expecting more tourists from China noting that tour operators selling Kenya in the Chinese market have reported positive forward bookings for this year. "As part of these campaigns, we have organized a media familiarization trip for CCTV channel 6, beginning mid this month for a two-week long visit to tourism attractions across the country. The TV channel is one of the powerful media outlets consumed by the Chinese and we believe this is one of the avenues to creating awareness on diverse tourism attractions in the country," said the MD.

"The market has shown remarkable growth in the past years. Last year however recorded a dip in arrivals in most of our leading tourist source markets. "China declined by 10.3 per cent to 37,062 visitors from 41,303 in 2012," said Mr. Ndegwa. Mr. Ndegwa is however optimistic that with improved cordial relations between the two countries, the industry envisages a growth in arrivals from China. "Mid last month, we hosted the largest delegation of Chinese tourists to ever visit the country, marking a major success for the country in tapping emerging markets for tourism especially in Asia and the Far East. "The group of 110 tourists toured leading sites in the country from April 12-16, including Hells Gate National Park, Masai Mara and the Aberdares," he said saying that was a major endorsement of Kenya as a leading destination These stories dwelt on the economic consequences of China's engagement with Kenya and focused on matters related to trade, investment, and loan policy. For example, the story "Forum opens doors to African investment" coded $31 / 10 / 23 / \mathrm{E} / 2$, falls under this category and talks about how China's investors are taking up economic opportunities in the African continent. "Horticultural business opportunity for Avocado farmers" coded 27/07/23/E/3, first, the Kenyan exporters in horticultural business have opportunity to leverage on this development to diversify sell of their produce dependent on traditional European market to the American market. Other sectors that will benefit include manufacturing, tourism and service industry. Overall, the direct flights will serve to expand the economic and employment opportunities by taking advantage of the many concessions offered under the Africa Growth and Opportunities Act to improve Kenya's thus enhancing balance of trade in Kenya's favor. (Daily Nation Tuesday April, 2017) Poor strategy dug Kenya into Chinese trade hole. China has stretched Kenya's hospitality, taking advantage of the country's open-door policy to flood the market with all manner of goods. Construction machinery, building materials, used clothing, onions, tilapia, tooth picks, toilet paper - no sector is safe from the 'Sino-invasion'

The other economic frame appeared in The Daily Nation May 142017 "Based on the common aspiration of our two peoples, China-Kenya pragmatic cooperation has been flourishing. Infrastructural cooperation has covered various fields, including railways, roads, airports, ports, communication, housing, water supply and power.

"The Mombasa-Nairobi SGR, as one of the benchmarks of BRI, has been completed in advance and operated safely and smoothly. Over 2.71 million passengers have travelled with SGR, with an average attendance rate of 99 per cent. Around 4.04 million tons of goods have been transported through the railway, with economic indicators surpassing expectations" Another economic frame is in The Standard Monday, June 182018 "China's other strategy in Africa has been through investment and trade. Chinese companies continue to invest in Kenya, even as leading business people from China visit to explore. Chinese firm Guangdong New South Group Limited, for example, signed a deal with the Kenyan government to build a $\$ 1.9$ billion industrial park in Eldoret.

\section{Mediatizing Cultural Ties / Social discourse}

These stories dwelt on human and cultural interaction between Chinese nationals and Kenya and focused on issues related to sports, festivals, tourism, Volunteerism, education, Art and Gallery etc. For example, the story "Back to school is the lesson" The Standard Tuesday, August 232019 falls under this category and encourages Kenyans to learn more about China's culture to help solidify Sino-Kenya relations.

In another article under Cultural ties, "It takes a village" by Abduel Elinaza coded 7/11/26/C/2; the sub-heading reads " $A$ Chinese expert on African Art and his wife, longtime residents of Kenya, fulfill their dream of opening a showcase for the continent's culture in Beijing". The Article emphasizes the importance of cultural links between China and Kenya. Mr. $\mathrm{Li}$, the owner of African Village in Beijing is quoted saying "It is not our personal property but a belonging of China, of future generations devoted to promoting African culture and art and ChinaAfrica friendship". China-Kenya cooperation headed for a brighter future (The Standard Tuesday, April 23 2019).

The University of Nairobi is the pioneer institution of higher education in eastern Africa. It has made progress in innovation while closely working with Chinese partners The Standard Monday, July 18 2018. The Confucius Institute is part of China's preoccupation with education.

\section{Mediatizing Political/Diplomatic Relations Discourse}

The political discourse advanced by the mainstream press in Kenya was that Kenya was in the race for shuttle diplomacy, state visits and military support from China and on the other hand China was faster cementing its place in the world geopolitics by looking for friendship from ready African countries, Kenya being one of them. The conclusion that such liberal values were under threat in Kenya, for example the story "China steps up its military cooperation" The Daily Nation, March 28 2016, falls under this category and talks about how China's enhanced military cooperation with Kenya is helping the Kenyan nation cope with terrorism. Another story is The Standard Tuesday APRIL, 232019 reads "Africa's place in geopolitics is prime but leaders must act" it talks about the world that wants to have a piece of Africa for a variety of reasons by exploring the opportunities and interests in their renewed vigour by the superpowers to invest or partner with 
the continent, China being one of the western states that are not left behind in the quest for a place in the world geopolitics by relating with Kenya closely. The Daily Nation Monday February 42019 has a headline that reads " State house is not quite sincere about China trip, signed deal" this editorial story was about president Kenyatta's trip and Raila Odinga to China in which when the media reported state house did not see the need to retract the claim this is an example of a shuttle diplomacy political relation in the same newspaper, "China: Display a flexing of its muscles" an editorial by Macharia Munene is about China showing its prowess in four ways namely: territory, population size, economy and world politics.

The same Standard newspapers further re-appropriated the geo-politics discourse due to the fact that it was ideologically inclined to the West and shared a similar position in its editorial policy. The story "China's "Chequebook diplomacy" has influenced all African countries to have much say in global geo-politics." questioned the huge loans given by China to be a trap as advanced by most of the western states. It further questioned whether the loan is driven by an underlying brand of win-win relations ideology advanced by China to sustain its place in world geo-politics. A reporter of The Standard Newspaper argued that the government of Kenya often disagreed with what the newspapers reported by simply accusing them of being agents of western ideology. See the excerpts from the interview below:

I think they (Kenyan government) wanted to perpetrate the myth that every negative thing that was happening in SinoKenya relations was as a result of the ... the local press was necessarily a puppet of the international media and part of this global conspiracy. The Standard Monday 4, 2019.

\section{References}

[1].Achberger, J. (2010). The Dragon Has Not Just Arrived: The Historical Study of Africa's Relations with China. History Compass, 8(5), 368-376.

[2].Aday, S. (2010). Leading the charge: Media, elites, and the use of emotion in stimulating rally Africa. CMI Brief, 3.

[3].Anderson, A. (1993). The Production of the Environmental Agenda. Leicester: Leicester University Press. Annals of tourism research, 24(3), 537-565.

[4].Asche, H (2008) China's Engagement in Africa - Opportunities and Risks for Development Hamburg: Africa Department, Economic Affairs (2008).

[5].Asp, K. (2014). News media logic in a new institutional perspective. Journalism Studies, 15(3),

[6].Atieno, J. (2016). An analysis of Kenya's mainstream print media's usage of objectification and anchoring to represent the Kenyan international criminal court cases in the daily nation and the standard news articles (Doctoral dissertation, Maseno university).

[7].Berg, J. W., Appelbaum, P. S., Lidz, C. W., \& Parker, L. S. (2001). Informed consent: legal theory and clinical practice. Oxford University Press.

[8].Chitty, N. (2008). China Soft. Revista do NP Comunicao Audiovisual da Intercom, Sao Paulo, v.1, N.1, p.155172 Jan./jun.2008.

[9].Chomsky, N. (2003). Understanding Power: The Indispensable Chomsky. London: Vintage.

[10]. Chui, W. H. (2007). Research methods for law. Edinburgh: Edinburgh University Press

[11]. Daily Nation. Retrieved from http://www.nation.co.ke/business/Appetite-for-Chinese-loans-costs-

[12]. Kenyansdearly-/-/ 996/3147468/-/j7p6h3/-/index.html

[13]. (September 20, 2016). The Big Question of Kenya's Piling Debt. The Daily Nation.

[14]. (August 22, 2016). Why Chinese Loans are a recipe for huge debt burden on Kenya.

[15]. De Vreese, C. H. (2005). News framing: Theory and typology. Information design journal \&

[16]. De Vreese, C.H. (2005). News framing: Theory and typology. Information Design Journal Document Design, 13(1): $51-62$

[17]. Kohut, A. (2001) 'Public Support for the Watchdog Is Fading', CJR (May/June): 52

[18]. Kolbe, R. H., \& Burnett, M. S. (1991). Content-analysis research: An examination of applications with directive for improving research reliability and objectivity. Journal of Consumer Research, 18(2), 243-250.

[19]. https://doi.org/10.1086/209256

[20]. Krippendorff, K. (2003) Content analysis: An introduction to its methodology (2 ${ }^{\text {nd }}$ ed.). London, UK: SAGE. 